\title{
急速圧縮膨張装置を用いた水素噴流の自着火・燃焼特性に関する研究*
}

\author{
光島敬太*1, 畑隆一*2, 过村拓*3 \\ 徳 永 佳 郎*4, 千田二 郎*5, 藤 本 元 $^{* 6}$
}

\section{Study on Characteristics of Auto-ignition and Combustion in Hydrogen Jet with a Rapid Compression and Expansion Machine}

Keita MITSUSHIMA, Ryuichi HATA, Taku TUJIMURA, Yoshiro TOKUNAGA, Jiro SENDA*7, Hajime FUJIMOTO

\footnotetext{
${ }^{* 7}$ Department of Mechanical Engineering, Doshisha University, 1-3 Miyakodani, Tatara, Kyotanabe-shi, Kyoto, 610-0321 Japan
}

\begin{abstract}
Hydrogen has a potential alternative to conventional hydrocarbon fuels, because no $\mathrm{CO}_{2}$ is emitted followed by combustion and it is able to make it by electroanalysis of water. This study aims to obtain stable ignition timing and combustion processes of hydrogen when it is applied into the direct-injection diesel engine. This report, it thought about the influence of the ambient conditions on the auto-ignition and combustion behavior of the hydrogen jet was investigated with a rapid compression and expansion machine (RCEM). First, the ambient temperature in combustion chamber is raised by adding argon into the ambient gas. Second, that is raised through the oxidation process of lean DME mixture. In addition, the effect of intermediates of DME reaction on the autoignition of hydrogen jet was investigated by use of CHEMKIN III code. Moreover, this effect was experimentally clarified.
\end{abstract}

Key Words : Diesel Engine, Alternative Energy, Combusion, Direct Injection, Hydrogen, Dimethyl Ether, RCEM, CHEMKIN

\section{1. 精}

二酸化炭素による地球温暖化問題は, 年々樑刻 化しており，次世代石油代替燃料への期待は非 常に大きなものとなっている。その中でも燃焼 により二酸化炭素を排出しない水素は究極の燃 料と考えられている.

内燃機関に水素を用いた研究は火花点火機関 に関するものが多い 1,2). しかし，火花点火機関 では圧縮比に制限を受け熱効率が低く，さらに 大型機関などへの適用は難しい，そこで，本研 究では熱効率が高く，機関サイズの制限がない 直接噴射式ディーゼル機関への水素適用に着目 した。これまでに本研究では，直接噴射式ディ 一ゼル機関を模擬した定容燃焼容器で実験を行

* 原稿受付 2007 年 4 月 6 日.

${ }^{* 1}$ 同志社大学大学院工学研究科(画 610-0321 京田辺市多々羅 都谷 1-3)

*2 学生員, 同志社大学大学院工学研究科.

*3 正員, (独) 産業技術総合研究所 (焉 305-8564 つくば市並木 1-2).

*4 正員, 川崎重工業(株) (恶673-8666 明石市川崎町).

*5 正員, 同志社大学工学部.

*6 正員, フェロー, 同志社大学工学部.

E-mail : jsenda@mail.doshisha.ac.jp
ない，水素噴流の混合気形成特性および自着火 特性などを明確にした ${ }^{3,4)}$. 一方, 実機関への適 用を考慮すると, 自着火温度の高い水素を安定 に自着火させるためには，通常より圧縮端温度 を上げる必要がある.この手法として本研究で は, 軽油と同等のセタン価を有するジメチルエ 一テル(以下 $\left.\mathrm{DME}, \mathrm{CH}_{3} \mathrm{OCH}_{3}\right)$ を予混合気に微量 添加し, 圧縮行程中の発熱により, 筒内のガス 温度の上昇を図る。

本報では，まず吸入空気に Ar を添加して急速 圧縮膨張装置（以下 RCEM）を用いて実験を行 ない，水素の持つ自着火・燃焼特性を明らかに した。続いて, DME を吸入空気に混合し, Ar を添加した際と同温度の雾囲気場を作成して実 験を行ない, $\mathrm{Ar}$ 添加時の自着火・燃焼特性と比 較した。 さらに水素噴射時における筒内の共存 成分が水素の自着火促進効果に与える影響につ いて, 詳細素反応モデルを用いた化学反応動力 学計算と実験結果の双方から検討した.

\section{2. 実䀫装置および素反応計算方法}

$2 \cdot 1$ 水素燃料喷射システム本研究では, 
水素ボンベからの供給圧力が低下した際も設定 噴射圧力に昇圧できるように, WE-NET の研究 5)により使用された装置を参照し，水素加圧・噴 射装置を設計・製作した，図 1 に装置の概略図 を示す，加圧装置は主に油厈ポンプ，ブラダ型 およびピストン型のアキュムレータで構成され ている。

噴射装置は噴射時期・期閒を任意に制御する ため, 高速応答電磁弁 (不二越, HS-G01-A21-D1-11) および電子制御の油压駆動 ガスインジェクタ(当研究室にて製作)で構成さ れている。また, ガスインジェクタにはギャッ プセンサ(電子応用, PU-03A)を取り付け, 噴射 毎の針弁リフト量を測定している.

\section{$2 \cdot 2$ 実硂装甼および实硂条件本実験で} は, RCEM の筒内に水素を直接噴射し, その自 着火・燃焼特性を調べた。本実験で使用する RCEMのボアは $100 \mathrm{~mm}$, ストロークは $450 \mathrm{~mm}$ である。また，RCEM のクランク軸にロータリ 一エンコーダを設置し，シリンダヘッド側面に 圧力センサを埋設した。水素噴射時の筒内温度

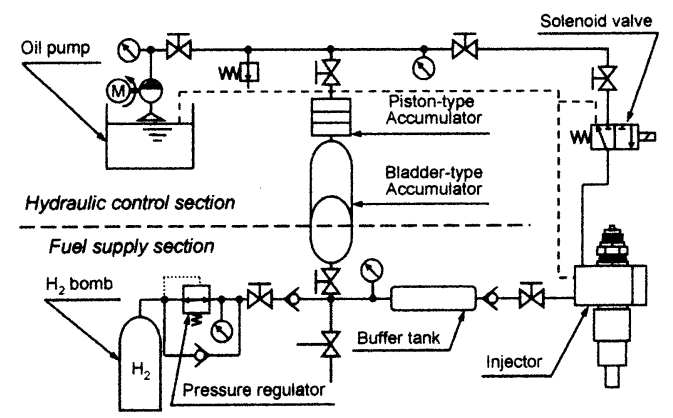

Fig.1 Schematic diagram of hydrogen fuel injection Tablel Experimental conditions for hydrogen auto-ignition measurement

\begin{tabular}{|c|c|c|}
\hline & Case 1 & Case 2 \\
\hline$\overline{\text { Fuel }}$ & \multicolumn{2}{|c|}{$\frac{1}{\mathrm{H}_{2}}$} \\
\hline Intake gas temperature & 353 & 333 \\
\hline $\begin{array}{l}\text { Injection pressure } p_{\text {inj }} \\
\left.\text { (Fuel density } \rho_{(n j}\right)\end{array}$ & \multicolumn{2}{|c|}{$\begin{array}{c}12 \\
(9.0)\end{array}$} \\
\hline Nozzle-hole diameter $d_{\text {, }}$ & \multicolumn{2}{|c|}{0.7} \\
\hline Equivalence crank speed & \multicolumn{2}{|c|}{200} \\
\hline Compression ratio $\varepsilon$ & 13 & 12 \\
\hline Premixed gas reactants & $\begin{array}{c}\mathrm{N}_{2} / \mathrm{O}_{2} / \mathrm{Ar} \\
\mathrm{N}_{2} / \mathrm{O}_{2} / \mathrm{DME}\end{array}$ & $\mathrm{N}_{2} / \mathrm{O}_{2} / \mathrm{DME} / \mathrm{Ar}$ \\
\hline $\begin{array}{l}\text { Ratio of added Ar ratio } \\
V_{a r}=\operatorname{ar} /\left(a r+N_{2}\right)\end{array}$ & $40-82$ & $0 / 13 / 23$ \\
\hline $\begin{array}{l}\text { Equivalence ratio of } \\
\text { Added DME фOME }\end{array}$ & $0.07-0.12$ & $0.1 / 0.08 / 0.06$ \\
\hline $\begin{array}{l}\text { Ambient gas compositions } \\
\text { at start of injection }\end{array}$ & $\begin{array}{c}\mathrm{N}_{2} / \mathrm{O}_{2} / \mathrm{Ar} \\
\mathrm{N}_{2} / \mathrm{O}_{2} / \mathrm{H}_{2} \mathrm{O} / \mathrm{CO}_{2}\end{array}$ & $\mathrm{~N}_{2} / \mathrm{O}_{2} / \mathrm{H}_{2} \mathrm{O} / \mathrm{CO}_{2} / \mathrm{Ar}$ \\
\hline Injection timing $t_{m j}$ & $-5.0 \pm 0.25$ & $-15.0 \pm 0.25$ \\
\hline $\begin{array}{l}\text { Ambient gas } \mathrm{O}_{2} \text { mol concentration }\left[\mathrm{moVm}^{3}\right] \\
\text { at hydrogen injection }\end{array}$ & \multicolumn{2}{|c|}{81.8} \\
\hline $\begin{array}{l}\text { Ambient gas temperature } \\
\text { at start of injection } T_{i n j}\end{array}$ & $900-1050$ & $800-830$ \\
\hline $\begin{array}{l}\text { Ambient gas pressure } \\
\text { at start of injection } p_{0} \\
\text { (Ambient gas density } \rho_{0} \text { ) }\end{array}$ & $\begin{array}{c}3.00-3.80 \\
(15.2-16.0) \\
(12.6)\end{array}$ & $\begin{array}{c}3.60-3.80 \\
(12.6)\end{array}$ \\
\hline
\end{tabular}

$T_{i n j}$ は, クランク角から算出された筒内容積と, 圧力センサにより得られた圧力から, 気体の状 態方程式を用いて導出した質量平均温度である. $\varepsilon=13$ において, 空気の断熱圧縮を仮定し理論的 に求めた圧縮端温度は $985 \mathrm{~K}$ となるが, 実験に おいては $760 \mathrm{~K}$ と低い。これはピストン速度が $200 \mathrm{rpm}$ 相当と非常に遅く, 壁面熱損失の影響が 大きいためである。使用した実験装置の概略図 を図 2 に, 実験条件を表 1 に示す. Case1 は3.1. 1 節から $3 \cdot 2 \cdot 2$ 節まで, Case 2 は $3 \cdot 2 \cdot 4$ 節の条件 である. 噴孔径 $d_{e}=0.7 \mathrm{~mm}$ の単噴孔ノズルを用い て, 任意の時期に噴射圧力 $P_{i n j}=12 \mathrm{MPa}$ で水素を 噴射した。本実験では吸入ガスとして $\mathrm{N}_{2} / \mathrm{O}_{2} / \mathrm{Ar}$ または $\mathrm{N}_{2} / \mathrm{O}_{2} / \mathrm{DME}$ を任意の割合で混合した。

Arは $\mathrm{N}_{2}$ などに比べ比熱比が高いため圧縮端温度 の上昇を図れる。また, DME は吸入ガスに添加 する事で圧縮により酸化反応を起こし発熱する ため, 筒内の温度が上昇する。これらの方法に より， $T_{i n j}$ を調節した。ここで, DME の酸化反応 により酸素が消費されるため, 本実験ではそれ を考慮し DME の当量比 $\phi_{D M E}$ の変化に合わせて 吸入ガス中の酸素モル濃度を変化させ, 水素の 反応に影響が出ない様に吸入ガスを作成した.

\section{$2 \cdot 3$ 添加物による発熱および㞣囲気温度展}

歴図3は圧縮比 $\varepsilon=13$ で吸入ガス中の各添加 物の量を変化した際の熱発生履歷および雾囲気

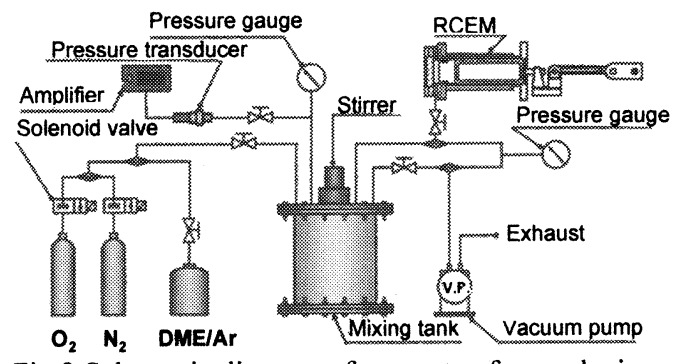

Fig.2 Schematic diagram of apparatus for producing and charging premixed gas with RCEM

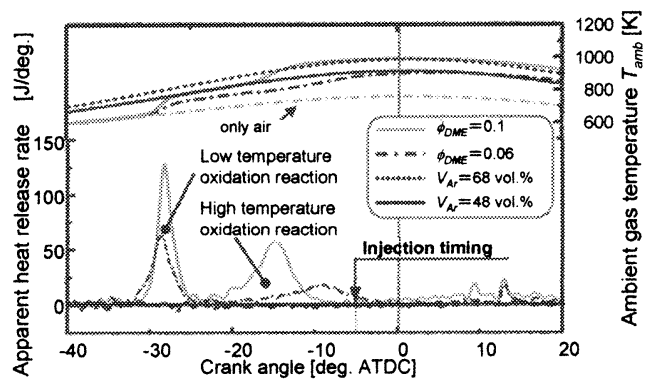

Fig. 3 Temporal change in ambient gas temperature and apparent heat release rate of DME 
温度 $T_{a m b}$ の履歴である。Ar の添加により，予混 合気の比熱は増大するため, 空気のみの温度履 歴より高い $T_{a m b}$ となる。また，Ar は不活性ガス のため発熱や吸熱が起こっていない。一方, $\mathrm{Ar}$ とは異なり活性な DME を添加した際は, 低温酸 化反応および高温酸化反応により $T_{a m b}$ が上昇す る.いずれの当量比においても DMEの低温酸化 反応の開始時期は一定である。一方， $\phi_{D M E}$ が低 下すると高温酸化反応の開始時期は遅角して緩 慢となり，-3 deg.ATDC 付近まで高温酸化反応に よる発熱が継続する。

$2 \cdot 4$ 自着火遅れ期間および熱発生率, 熱変換 効率の定義 図 4 に RCEM 内での水素の熱発 生率履歴と針弁リフト波形を示す。本実験では 自着火開始時期を水素噴射から熱発生率が 20 $\mathrm{J} / \mathrm{deg}$.を超えた時点とし, 水素噴射から自着火開 始時期までの期間を自着火遅れ期間 $\tau_{p}$ と定義す る。本実験では壁面での熱損失を考慮しない， みかけの熱発生率を次式から求めた。

$$
\dot{Q}_{\theta}=\frac{d Q}{d \theta}=\frac{1}{\kappa-1}\left(V \frac{d p}{d \theta}+\kappa p \frac{d V}{d \theta}\right)
$$

また，以下のように見かけの熱発生率を積算 した総熱発生量を, 噴射された水素の投入熱量 で除した值を熱変換効率 $\eta_{h c}$ と定義する。

$$
\eta_{h c}=\int^{\nu_{c o m b}} \frac{\dot{Q} d t}{m \cdot Q_{L H V}}=\frac{Q}{m \cdot Q_{L H V}}
$$

\section{$2 \cdot 5$ 素反応計算化学反応速度計算には} CHEMKINIIIの AURORA アプリケーションを用 いて, 燃焼室内の温度・濃度分布がなく，断熱 変化と仮定した 0 次元のもとで計算を行なった. DME の反応モデルには，2000 年に Curran らが 提案した反応スキーム(DME2000: 素反応数 351 , 化学種数 79) ${ }^{6)}$ を使用し解析を試みた. Curran ら のモデルは DME の酸化反応時期の当量比, 温度, 圧力依存性および負の温度勾配領域を再現可能

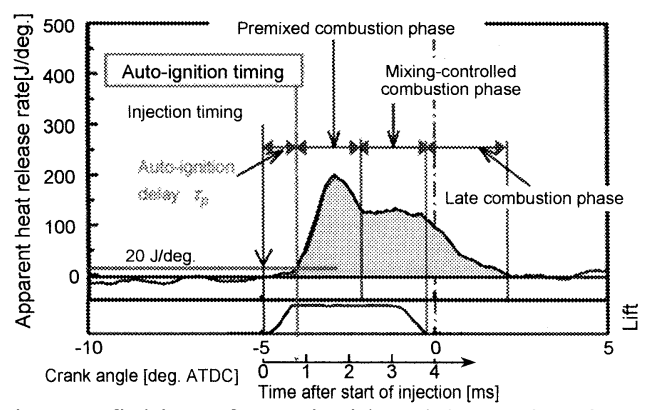

Fig.4 Definition of auto-ignition delay and various combustion phase
である ${ }^{7)}$.

\section{3. 実験結果および考察}

$3 \cdot 1$ 吸入ガスに Ar を添加した場合の自着 火・燃焼特性 過去の研究 ${ }^{3)}$ により，水素の $\tau_{p}$ は $1000 \mathrm{~K}$ 以上の高温度域において比較的短くな ることが示されている。そのため, 空気を吸入 し圧縮して $1000 \mathrm{~K}$ 付近まで温度を上昇させるた めには， $\varepsilon=20$ 付近まで上げなければならない。 しかし，高過ぎる圧縮比は，冷却損失，機械損 失の増大を招くため効率が低下する。そこで， 本実験では WE-NET の研究5)同様に比熱比の高 いAr を吸入ガスに添加して温度上昇を図った。

\section{$3 \cdot 1 \cdot 1$ 雾囲気温度と雾囲気酸素の体積モル} 濃度が自着火遅れ期間へ与える影響 $\quad \varepsilon=13$ ，

噴射圧力 $P_{i n j}=12 \mathrm{MPa}$ で噴射時期 $t_{i n j}=-5$ deg.ATDC, 水素噴射時の筒内容積 $V_{i n j}=305 \mathrm{~cm}^{3}$ 中へ水素を噴射し, 䨌囲気酸素の体積モル濃度 が 81.8, 70.2, $59.4 \mathrm{~mol} / \mathrm{m}^{3}$ と変化した際の水素噴 射時の温度 $T_{i n j}$ と自着火遅れ期間 $\tau_{p}$ の関係を図 5 に示す。併せて，過去に行なった同様の噴射条 件における定容然焼容器を用いた実験結果を図 5 に破線で示す。 なお，これらの䨌囲気酸素の体 積モル濃度は, 吸入ガス全体における体積割合 に換算するとそれぞれ，21，17，15 vol.\%に相 当する. 本節では表 1 の Case1 で示すように, $T_{i n j}$ は $\mathrm{Ar}$ の投入割合 $V_{A r}=\mathrm{Ar} /\left(\mathrm{Ar}+\mathrm{N}_{2}\right)$ を $V_{A r}=48-70$ vol.\%と変化させて調節した. $T_{i n j}$ の低下に伴ない $\tau_{p}$ が長期化する温度依存性が確認できる. $\mathrm{H}_{2}$ と $\mathrm{O}_{2}$ を起源とする連鎖反応により水素の自着火反 応に重要な $\mathrm{H}_{2} \mathrm{O}_{2}$ が生じる.この $\mathrm{H}_{2} \mathrm{O}_{2}$ の熱分解 反応により生成される $\mathrm{OH}$ ラジカルは自着火反 応を促進するが, $1100 \mathrm{~K}$ 以下の温度域では $\mathrm{H}_{2} \mathrm{O}_{2}$ の反応が緩慢になり, $\mathrm{OH}$ ラジカルの生成量が低 下する。その結果, 自着火誘導時間が増加する

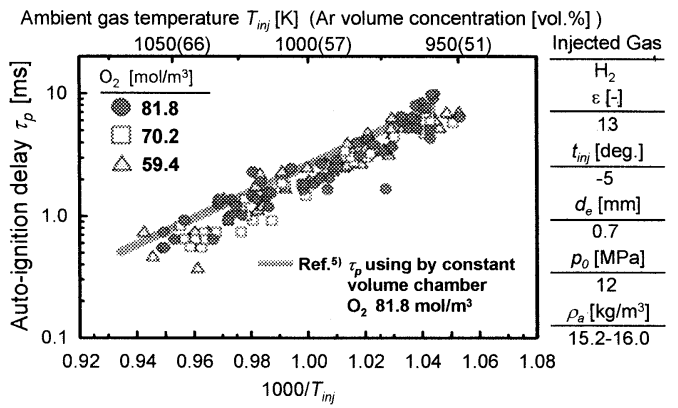

Fig.5 Effects of ambient gas $\mathrm{O}_{2}$ concentration on auto-ignition delay 
8).さらに温度が低下すると, 水素噴射に伴なう 強い乱流作用が水素鋠度および温度の急激な変 化を招き, 活性化学種の散逸・失活する可能性 が高くなり自着火に至る確率が低下する ${ }^{9)} .1100$ $\mathrm{K}$ 以下の温度域となる本研究の RCEM 実験によ る結果でも同様の理由から温度依存性が見られ たと考えられる.

以前の研究において, 定容燃燒容器を用いて $\tau_{p}$ の温度依存性について考察を行なった.その中 で $1100 \mathrm{~K}$ 以上の温度域では温度依存性が小さく, それ以下の温度域になると温度依存性が大きく なる ${ }^{5)}$ 事を確認している.

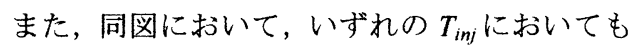
雾囲気酸素の体積モル濃度が $\tau_{p}$ に与える影響は ほとんど見られない。これについても先の論文

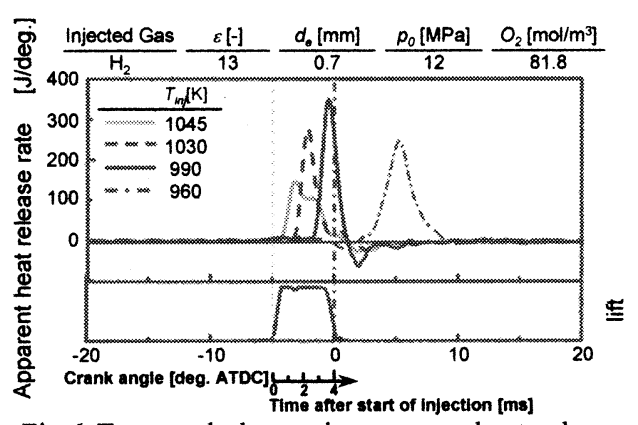

Fig.6 Temporal change in apparent heat release rate with ambient gas temperature

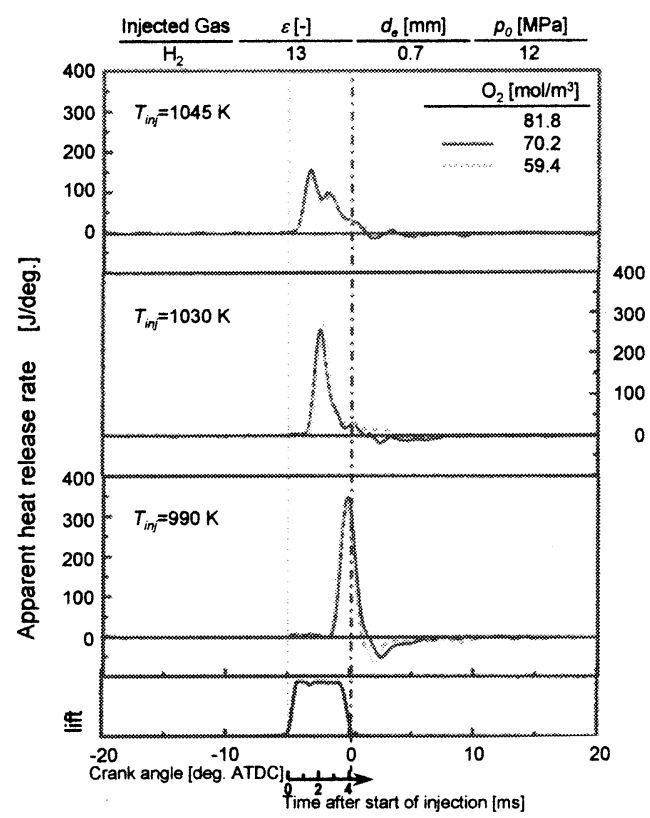

Fig.7 Temporal change in apparent heat release rate with $\mathrm{O}_{2}$ concentration
10)と同様の結果を得た.

\section{$3 \cdot 1 \cdot 2$ 㞣囲気温度と冬囲氛酸素の体䅡モル}

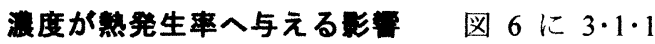
項と同様の噴射条件において水素噴射時の塞囲 気酸素の体積モル濃度を $81.8 \mathrm{~mol} / \mathrm{m}^{3}$ 一定とし, $T_{i n j}$ を変化した際の, 水素の熱発生率履歷を示す. $T_{i n j}=1045 \mathrm{~K}$ の高温度条件に㧍いては $\tau_{p}$ が短いた め, 拡散的燃焼が起こる。 $T_{i n j}=1030 \mathrm{~K}, 990 \mathrm{~K} の$ 条件では， $\tau_{p}$ の長期化により自着火までに生成 される予混合気量が増加し，さらに上死点付近 の高温度場において自着火が起こっているため, 熱発生率のピークの高い燃焼が行なわれている. さらに $T_{i n j}$ が低下すると膨張行程での燃焼にな るため，燃焼期間の長い穏やかな燃焼が起こっ ている.

次にそれぞれの $T_{i n j}$ において雾囲気酸素の体 積モル濃度を $81.8,70.2,59.4 \mathrm{~mol} / \mathrm{m}^{3}$ と変化させ た際の熱発生率履歴を図 7 に示す。熱発生率履 歴を比較するため, 各 $T_{i n j}$ において $\tau_{p}$ が同等とな るデータを選んだ. $T_{i n j}=1045 \mathrm{~K}, 1030 \mathrm{~K}$ におい て, 雰囲気酸素の体積モル濃度の低下に伴ない, 僅かながら拡散燃焼後の後燃え期間における熱 発生率が减少し，燃焼期間が長期化する。一方， $T_{i n j}=990 \mathrm{~K}$ では雾囲気酸素の体積モル濃度に関わ らず概ね同様の熱発生率履歴を示す。

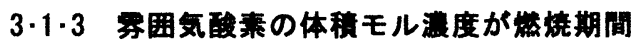
に与える影福図 7 の熱発生率履歴から雾囲 気酸素の体積モル濃度は燃焼期間に影響を及ぼ すと考えられる. そこで図 8 に雰囲気酸素の体 積モル濃度を変化した際の $\tau_{p}$ と, 燃焼期間 $t_{c o m b}$ を噴射期間 $t_{i n j d u r}$ で正規化した $t_{c o m b} / t_{i n j \_d u r}$ の関係 を示す. いずれの条件においても， $t_{i n j d u r}$ は約 4 $\mathrm{ms}\left(5 \mathrm{deg}\right.$ ) である. $\tau_{p}=2-4 \mathrm{~ms}$ の領域において $t_{\text {comb }} / t_{\text {inj_dur }}$ は最も短く一定であり, また, 雾囲気 酸素の体積モル濃度の影響はほとんど見られな い.この領域では自着火までに時間を要してい

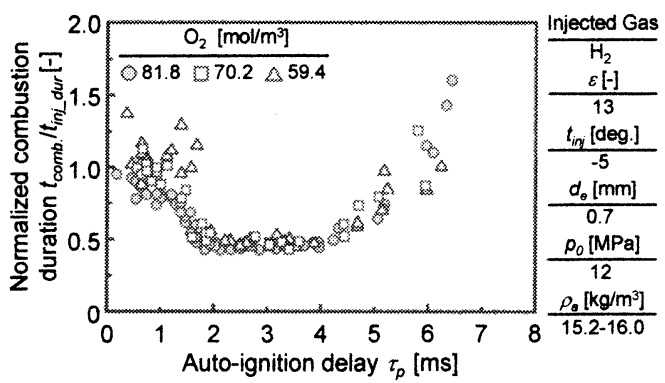

Fig.8 Effect of auto-ignition delay on normalized combustion duration 
るため，予混合燃焼が主であること，さらに上 死点近傍における燃焼であることから，短時間 の急激な燃焼が行なわれる。一方， $\tau_{p}=2 \mathrm{~ms}$ 以下 では $t_{\text {comb }} / t_{i n j \_d u r}$ が増加する.この領域では $\tau_{p}$ が短 いため，水素噴射中に同時に燃焼が行なわれる 拡散的燃焼が主となっているためと推察される. また，僅かに雾囲気酸素の体積モル濃度の低下 に伴なう $t_{c o m b} / t_{i n j \_d u r}$ の增大が見られる. 雾囲気酸 素の体積モル濃度が低い際, 抎散的燃焼期間に おいて酸素との反応が緩慢になると考えられる. そのため, 水素噴射終了後に残存する未燃水素 が増加し, 雾囲気酸素の体積モル濃度の低下に 伴ない後燃え期間が長期化するため $t_{\text {comb }} / t_{\text {inj_dur }}$ が大きくなったと考えられる.

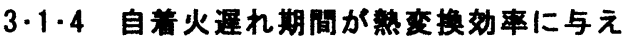
る䝑霍囲気酸素の体積モル濃度 81.8, 70.2, $59.4 \mathrm{~mol} / \mathrm{m}^{3}$ において, $\tau_{p}$ が水素の熱変換効率 $\eta_{h c}$ に与える影響を図 9 に示す。 $\tau_{p}=2 \mathrm{~ms}$ 以下におい て， $\eta_{h c}$ は概ね 0.3 の值を示し， $\tau_{p}$ の長期化に伴 ない $\eta_{h c}$ は上昇する.これは $\tau_{p}$ の長期化に伴ない 比較的均一希薄な水素予混合気が作成され，末 燃水素の減少，火炎内温度の低下が招く冷却損 失の减少等が主要因であると推察される。また， 雾囲気酸素の体積モル濃度について比較すると， 雾囲気酸素濃度 $59.4 \mathrm{~mol} / \mathrm{m}^{3}$ の条件において多少 ばらつきがあるが, 雾囲気酸素の体積モル濃度 が水素の熱変換効率に与える影響は小さいと考 えられる。

\subsection{DME を添加した场合の自着火・㘹烧特性}

$3 \cdot 1$ 節では吸入ガスに不活性ガスである Arを 加えて圧縮端温度を変化させ実験を行い, 水素 の自着火・燃焼特性を把握した。しかし， $\mathrm{Ar}$ は 地球上での存在量が少ないために実用的ではな い.そこで本研究では，Ar の代わりに常温・常 圧で気体である DMEを，吸気に少量添加するこ とにより筒内温度を上昇させ，水素を自着火さ

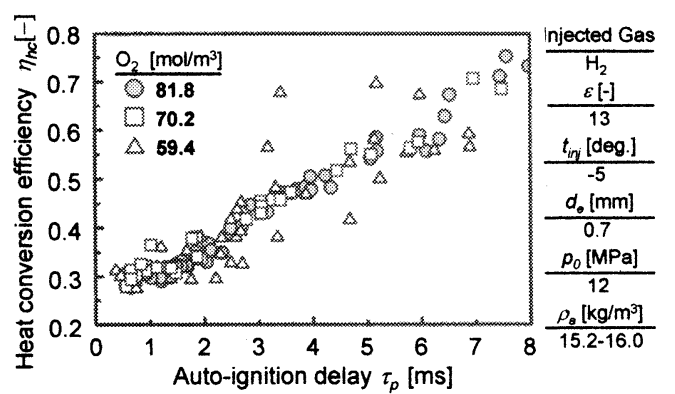

Fig.9 Effect of auto-ignition delay on heat conversion efficiency
せることを試みた。

\subsection{1 自着火逗れ期間への影零 水素噴} 射時の雾囲気酸素の体積モル濃度を $81.8 \mathrm{~mol} / \mathrm{m}^{3}$ とし，DME または Ar を吸入空気に添加した際 の, $\tau_{p}$ と $T_{i n j}$ の関係を図 10 に示す. 本実験では, 吸入する $D M E$ の当量比を $\phi_{D M E}=0.07-0.12$ と変化 させ， $T_{i n j}$ を調節した．Ar および DME 添加のい ずれの条件においても $T_{i n j}$ の上昇に伴ない $\tau_{p}$ が短 縮されている. $T_{i n j}=1050 \mathrm{~K}$ 付近の高温度域では Ar および DME 添加の条件において，同等の $\tau_{p}$ が得られた． $T_{i n j}$ の低下に伴ない, Arを添加した 条件に比べて DME を添加した条件の方が僅か に $\tau_{p}$ が短縮する，さらに，Ar を添加した条件で は $T_{i n j}=950 \mathrm{~K}$ 以下の温度域ではほとんど自着火 には至らなかった。一方，DME を添加した条件 では $\tau_{p}$ が長いものの, $T_{i n j}=900 \mathrm{~K}$ 以下まで安定な 自着火が得られた。したがって, DMEの酸化反 応が水素の自着火反応に需囲気温度上昇以外の 影響を与えていることが推察される.

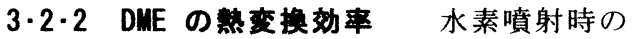
DME の反応状態を把握するために, 水素噴射時 までの DME の低温酸化反応・高温酸化反応によ る発熱量 $Q_{D M E}$, 投入した DME の総熱発生量 $m \cdot Q_{D M E} L H V$ で除した次式で示される熱変換効率 $\eta_{D M E}$ で評価する。

$$
\eta_{D M E}=\int^{N_{\text {canb }}} \frac{Q d t}{m \cdot Q_{D M E_{-} L H V}}=\frac{Q_{D M E}}{m \cdot Q_{D M E_{-} L H V}}
$$

水素噴射時までの $\eta_{D M E}$ と $\phi_{D M E}$ の関係を図 11 に 示寸. $\phi_{D M E}=0.11$ の条件で $\eta_{D M E}$ は 0.3 を超えるも のの, $\phi_{D M E}$ の低下に伴ない $\eta_{D M E}$ が減少しており， 全体的に低い $\eta_{D M E}$ である.これは低当量比ほど, 反応が緩慢になり相対的に DME の未燃分が増 加したと考えられる. 金野らはDMEの反応によ り生成される $\mathrm{H}_{2} \mathrm{O}_{2}, \mathrm{HCHO}$ などの中間生成物が

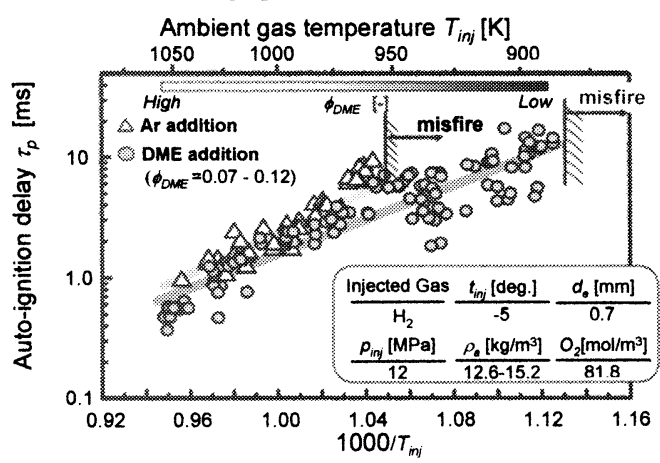

Fig.10 Effect of Ar addition and DME addition on auto-ignition delay 
主燃料の反応に影響を与える ${ }^{10)}$ と報告している. したがって本実験においても， $\phi_{D M E}$ が低い条件 では水素噴射時において筒内に未反応の DME, $\mathrm{H}_{2} \mathrm{O}_{2}, \mathrm{HCHO}$ および反応性の高い $\mathrm{OH}$ ラジカル などの成分が存在し, 水素の自着火に影響を及 ぼした可能性がある.

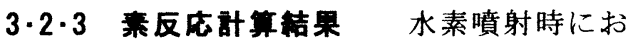
ける筒内の共存成分が水素の自着火に及ぼす影 響を調べるため，吸入ガスに DME を加えた条件 で素反応計算を行なった。機関条件は本実験で 使用した RCEM と同様, ボアメストロークは 100 $\mathrm{mm} \times 450 \mathrm{~mm}, \varepsilon=13$, 回転数は $200 \mathrm{rpm}$ とし, 初 期温度を $353 \mathrm{~K}$, 初期圧力を $0.1 \mathrm{MPa}$ とした. 計 算結果の一例として, $\phi_{D M E}=0.03$ における $\mathrm{CH}_{3} \mathrm{OCH}_{3}, \mathrm{H}_{2} \mathrm{O}_{2}, \mathrm{HCHO}$ および $\mathrm{OH}$ モル濃度経 過を, 図 12 に示す.さらに同様の計算を各 $\phi_{D M E}$ について行い, 実験における水素噴射時である-5 deg.ATDC の共存成分に着目し, それらのモル分 率を各 $\phi_{D M E}$ について整理したものを図 13(a)に示 す. 低当量比において $\mathrm{H}_{2} \mathrm{O}_{2}, \mathrm{HCHO}$ の成分が多 い.これらの成分は低温酸化反応で生成され, 高温酸化反応により消費される。しかし， $\phi_{D M E}$ の低下に伴ない低温酸化反応による発熱が小さ くなり, 高温酸化反応開始時期が遅角する.さ

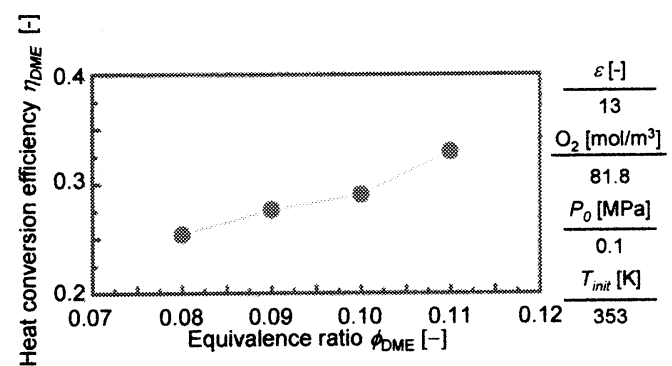

Fig.11 Effect of DME equivalence ratio on heat conversion efficiency

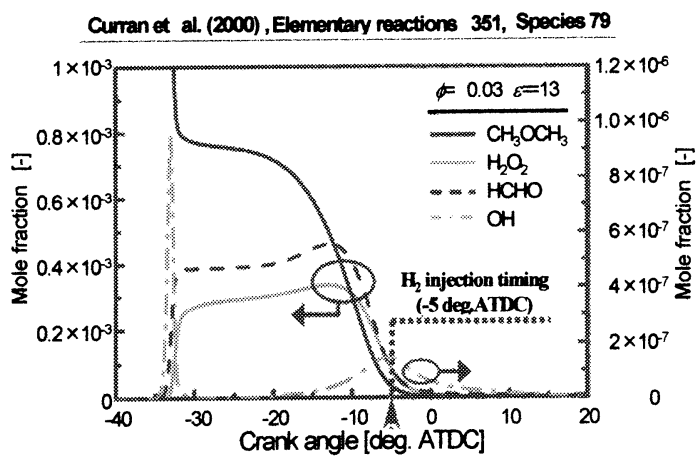

Fig.12 Profile of chemical species mole fraction as a function of crank angle ( $\left.\phi_{D M E}=0.03\right)$
らに $\phi_{D M E}$ を低下させると, 十分に温度が上昇せ

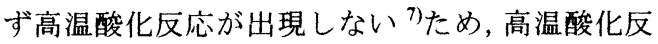
応で消費されるはずの化学種が反応せずに筒内 に残存する. 一方, 当量比が高い条件では高温 酸化反応により $\mathrm{H}_{2} \mathrm{O}_{2}$ および $\mathrm{HCHO}$ が消費され, $\mathrm{OH}$ ラジカルが生成し增加する。

次にこれらの化学種が水素の自着火反応に与 える影響について検討する. 安定な自着火反応 は局所的に水素の当量比が $\phi=1.0$ の付近で起こ ると考えられる。そこで, 図 13(a)より得られた モル濃度の化学種が当量比 $\phi=1.0$ の水素と同じ 場に存在すると仮定し, 各々の $\phi_{D M E}$ について計 算した。計算条件は RCEM 実験を考慮し, 初期 圧力 $P_{0}=3.5 \mathrm{MPa}$ おうよび初期温度 $T_{0}=1000 \mathrm{~K}$ で圧 カ一定とした。ここで, 本計算において自着火 開始は生成する $\mathrm{H}_{2} \mathrm{O}_{2}$ のモル濃度の増加率が負に 転じた時期とし， $\tau_{p}$ は計算開始から自着火開始時 期までの期間とした。その結果より得た化学種 と $\tau_{p}$ の関係を図 13(b)に示す. 図 13(a)において $\mathrm{CH}_{3} \mathrm{OCH}_{3}$ は $\phi_{D M E}=0.01-0.03$ ではモル濃度が高い にもかかわらず，水素の自着火促進効果はほと んどない。一方, 他の共存成分は自着火促進効 果を有し, 特に $\mathrm{H}_{2} \mathrm{O}_{2}$ は影響が大きく, 高当量比 ではわずかしか存在しないものの, $\tau_{p}$ が短縮され ている.これは $\mathrm{H}_{2} \mathrm{O}_{2}$ の熱分解反応により多量の $\mathrm{OH}$ ラジカルを生成するためと考えられる.また, $\phi_{D M E}$ が低い条件の方が高い条件に比べ自着火が

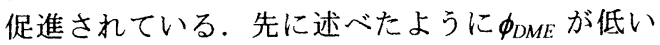
条件では高温酸化反応開始時期が遅角し, -5

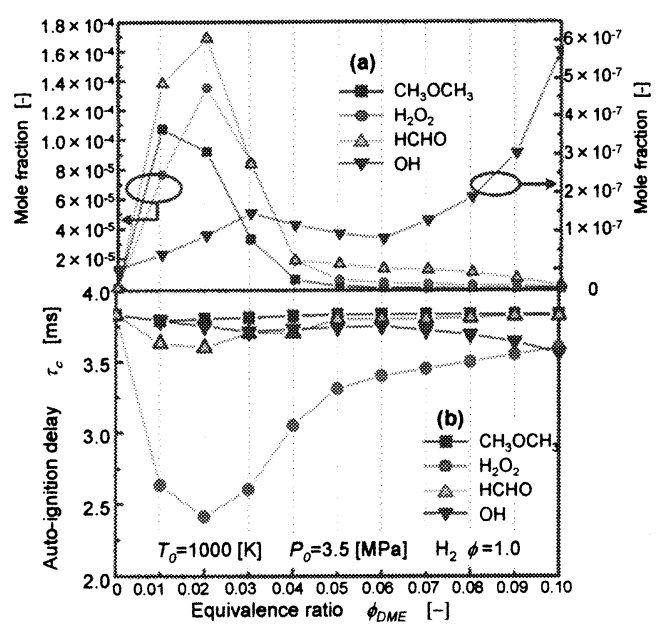

Fig. 13 Mole fraction of DME chemical species at -5 deg.ATDC and effect of chemical species on auto-ignition delay 
deg.ATDCにおいて $\mathrm{H}_{2} \mathrm{O}_{2}$ や $\mathrm{HCHO}$ などの中間生 成物が多量に残存するため，これらの共存成分 の反応が多くの $\mathrm{OH}$ ラジカルを生成し, 水素の自 着火を促進すると考えられる，RCEM 実験にお いては筒内温度や混合気の不均一性および壁面 における冷却により，さらに多くの共存成分が 水素噴射時に含まれていると考えられる。した がって, 図 10 のように $\mathrm{Ar}$ 添加の条件に比べて DME 添加の条件の方が $\tau_{p}$ の短期化が見られ，低 温度域においても安定な自着火に至ったと考え られる。

\subsection{4 中間生成物が有する水素の自着火促} 進奻果の実㰸的把暒 DME の高温酸化反忘は, 低温酸化反応により蓄積された $\mathrm{H}_{2} \mathrm{O}_{2}$ の熱解離に より引き起こされる. $3 \cdot 2 \cdot 3$ 節の計算により得ら

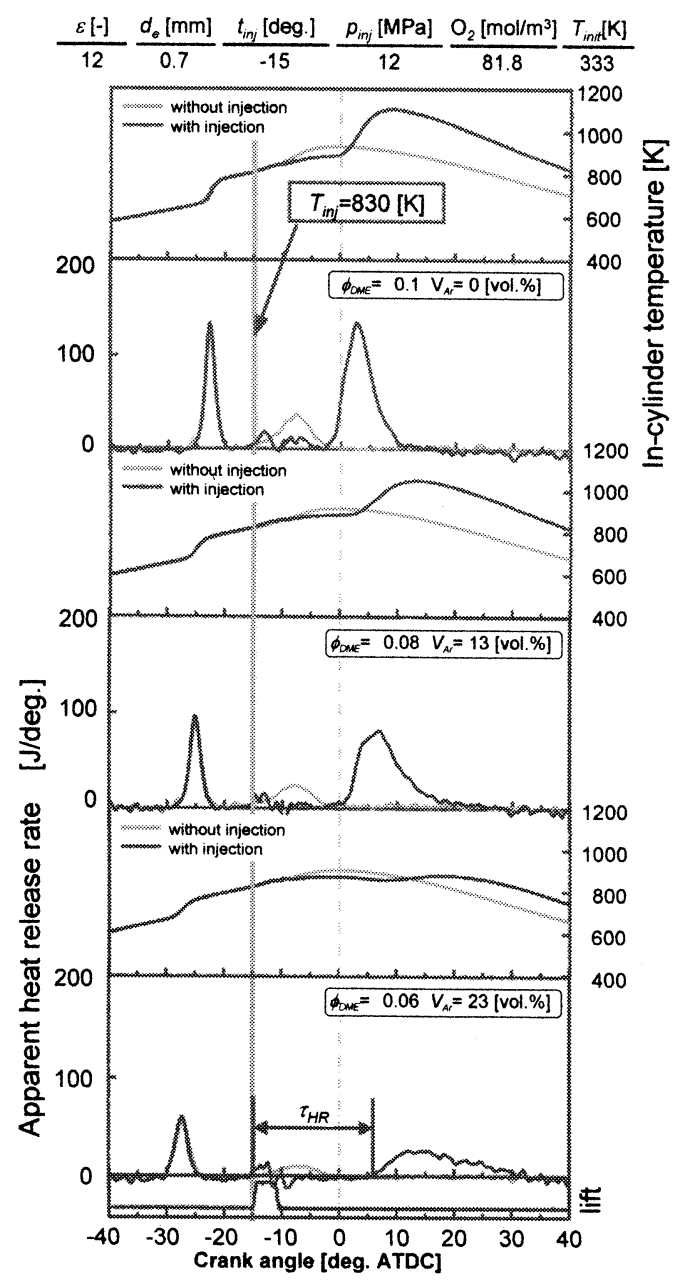

Fig.14 Effect of intermediate product on auto-ignition delay of hydrogen
れた結果は, DMEの反応による中間生成物の中 でも, $\mathrm{H}_{2} \mathrm{O}_{2}$ の蓄積量が水素の自着火を促進する 効果が大きいことを示した。そこで，この影響 を実験的に調べるため, $\mathrm{H}_{2} \mathrm{O}_{2}$ が最も多く蓄積さ れる高温酸化反応前に水素を噴射した。

高温酸化反応は，概ね一定の温度で発現する とされる ${ }^{11)}$. そのため，いずれの $\phi_{D M E}$ の条件に おいても, $t_{i n j}=-15 \mathrm{deg}$.ATDC が高温酸化反応開始 時期となるように $V_{A r}=0,13,23 \mathrm{vol} \%$ と変化さ せて, $T_{i n j}=830 \mathrm{~K}$ に揃え，水素噴射時における $\mathrm{H}_{2} \mathrm{O}_{2}$ の蓄積量のみを変化可能な条件を設定した。 なお，本節の実験においては，表 1 の Case2 に 示すように高温酸化反応開始時期を上死点に近 づけるために， $\varepsilon=12$ および吸入ガス温度を 333 $\mathrm{K}$ とした. DMEの当量比 $\phi_{D M E}$ と $\mathrm{Ar}$ vol. \%の投入 割合を, $\phi_{D M E} / V_{A r}=0.10 / 0,0.08 / 13,0.06 / 23$ とした 際の熱発生率および筒内温度履歴を図 14 に示す. いずれの非噴射時の条件においても, DMEの高 温酸化反応による発熱, 温度上昇が起こってい る.しかし，水素を噴射した場合においては， 全ての条件において，DMEの高温酸化反応によ る発熱および筒内温度上昇が抑制されている。 これは, 水素が DMEの高温酸化反応を引き起こ すプロセスに影響を与えたからと考えられる。 DME の高温酸化反応は $\mathrm{H}_{2} \mathrm{O}_{2}$ の熱解離により多 量に生成される $\mathrm{OH}$ ラジカルが $\mathrm{HCHO}$ と反応し 発熱する。そこで, 高温酸化反応の起因となる $\mathrm{HCHO}$ および噴射された水素の $\mathrm{OH}$ ラジカルと の反応性について検討する.

図 15 は図 13 の $\phi_{D M E}=0.02$ の条件を計算した際 の $\mathrm{HCHO}$ および $\mathrm{H}_{2}$ の $\mathrm{OH}$ ラジカルとの反応速度 を比較したものである. 反応速度がピークを示 す時期は両者とも概ね同じであるが， $\mathrm{H}_{2}$ の $\mathrm{OH}$ ラジカル消費速度は, $\mathrm{HCHO}$ のそれに比べ非常 に速く, $\mathrm{HCHO}$ の $\mathrm{OH}$ ラジカル消費速度の最大 1800 倍の速さに達する. したがって, 高温酸化 反応直前に水素が投入されることにより, $\mathrm{OH}$ ラ

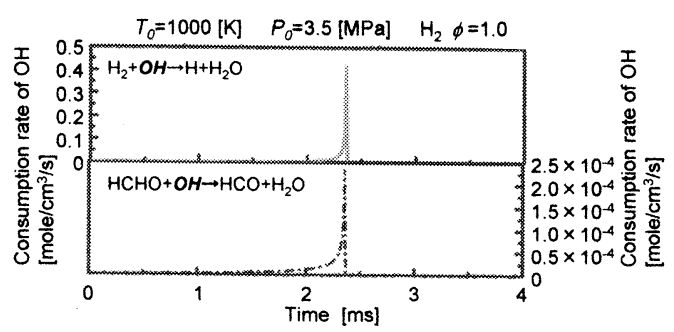

Fig. 15 Comparison of consumption rate of $\mathrm{OH}$ in $\mathrm{H}_{2}$ and $\mathrm{HCHO}\left(\phi_{D M E}=0.2\right.$ in fig. $\left.13(\mathrm{~b})\right)$ 
ジカルは水素と優先的に反応し, DME の高温酸 化反応が抑制されたと考えられる。

次に図 14 の各 $\phi_{D M E} / V_{A r}$ の条件における熱発生 率について比較すると， $T_{i n j}$ が同じ条件であるに も係わらず， $\phi_{D M E}$ が高い条件ほど水素噴射から 熱発生に至るまでの時間 $\tau_{H R}$ が短く, 熱発生も大 きい，非噴射時の熱発生および温度履歴からも 確認できるように， $\phi_{D M E}$ が高いほど高温酸化反 応直前に蓄積された中間生成物の量も多くなる。 そのため，水素の自着火に大きな影響を及ぼす $\mathrm{H}_{2} \mathrm{O}_{2}$ が多く蓄積されている。したがって，高温 酸化反応前に水素を噴射する実験においては, $\phi_{D M E}$ が高くなるにつれ $\mathrm{OH}$ ラジカルも多量に供 給されるため, $\mathrm{OH}$ ラジカルと水素との反応が活 発となり，水素の反応が促進された結果， $\tau_{H R}$ が 短期化されたと考えられる.

以上より，DMEの高温酸化反応が水素の噴射 により抑制され，代わりに水素の自着火を促進 することを実験的に証明した。これは, $3 \cdot 2 \cdot 3$ 節 の化学反応動力学計算により得た DME の $\mathrm{H}_{2} \mathrm{O}_{2}$ による水素の自着火促進効果を, 実験的に実証 するものである.

\section{4. 結吾}

(1) 水素の自着火遅れ期間は雾囲気酸素の体積 モル濃度の影響を受け難い。しかし，熱発生 率および燃焼期間は, 高温度域で雾囲気酸素 の体積モル濃度の影響を僅かに受ける。

(2) 水素の自着火遅れ期間が $8 \mathrm{~ms}$ までの領域で は, 自着火遅れ期間の長期化に伴ない, 熱変 換効率は高くなる。

(3) 雾囲気温度が低下すると $\mathrm{Ar}$ 添加時は $950 \mathrm{~K}$ 程度で失火するが，DME 添加時は $900 \mathrm{~K}$ 以 下まで安定な自着火を得る。

(4) DME の高温酸化反応前に水素を噴射すると, 高温酸化反応は抑制され, 水素の自着火が促 進される。

（5）DME の当量比が低い際，水素噴射時におい て多く存在する $\mathrm{H}_{2} \mathrm{O}_{2}$ により $\mathrm{OH}$ が生成され， 水素の自着火を促進する。

\section{融 辞}

本研究は文部科学省学術フロンティア推進事 業「次世代ゼロエミッション・エネルギー変換 システム」(同志社大学)の支援を受けた。ここに 記して謝意を表す。

\section{文}

(1) Shioji, M. et al., Combustion Process and Performance in a Compact High-Speed Hydrogen Engine, Proceedings of convention of JSAE, No.3, pp.9-12, (2000).

(2) Shudo, T. et al, Analysis of Degree of Constant Volume and Cooling Loss in a Hydrogen Premixed Combustion Engine, Transactions of JSAE, vol.31, No.4, pp5-10, (2000).

(3) Ohta, A. et al, A study on Auto Ignition Characteristic of unsteady Gas Jet-Measurements of Auto-ignition Delay and Location by Means of $\mathrm{OH}$ Chemiluminescence Image -, Proceedings of the $41^{\text {st }}$ symposium on combustion, pp.89-90, (2003).

(4) Ueda,Y. et al, Measurement of fuel concentration distribution of unsteady gas jet by Rayleigh scattering, Proceedings of convention of JSAE, No.107-04, pp.5-8, (2004).

(5) Sanyo T., Development of Hydrogen powered Diesel Engine, Combustion Study N0.115, pp43-53, (1999).

(6) H. J. Curran, et al, The Reaction Kinetics of Dimethyl Ether. II: Low-Temperature Oxidation in Flow Reactor, Int. J. Chem. Kinet. , Vol.32, No.12, pp741-759, (2000).

(7) Koyama, T. et al, Numerical Calculation of the Ignition and the Combustion in Homogeneous Charge Compression Ignition Engine by using an Elementary Reaction Model in Case of Dimethyl Ether, JSME (B), Vol.67, No.657, pp.172-179, (2001).

(8) Koshi, M., Simulation of Hydrogen Combustion at High Pressure, science and technology of combustion, Vol.7, pp.153-162(2000)

(9) Takahashi, S, Development of hydrogen diesel engine system(in Japanese), Journal of the Combustion Society of Japan,No.115, pp.43-53(1999).

(10) Konno, M., Effect of Coexistence Components on HCCI Process, Transactions of JSAE, vol.36, No.5, pp.47-52, (2005).

(11) Iida, N., The key Points of HCCI combustion Controls, 2004 IFP International Conference, PP.29-44, (2004). 